УДК 343.1

DOI https://doi.org/10.32837/pyuv.v0i1(30).548

\author{
I. М. Чемерис \\ https://orcid.org/0000-0002-8583-6282 \\ аспірант кафедри галузевого права \\ Херсонського державного університету, \\ заступник керівника \\ Херсонської місиевої прокуратури
}

\title{
ВИКОРИСТАННЯ СПЕЦІАЛЬНИХ ЗНАНЬ, ПРИЗНАЧЕННЯ ЕКСПЕРТИЗ ТА АРЕШТ БЕЗГОТІВКОВИХ КОШТІВ ЯК ЗАСІБ ЗАБЕЗПЕЧЕННЯ ПОДАЛЫШИХ СЛІДЧИХ ДІЙ
}

Вступ. Дорожньою картою для слідчого у кожному кримінальному провадженні є положення ст. 91 Кримінального процесуального кодексу України (далі - КПК України), якою визначено обставини, що підлягають доказуванню у кримінальному провадженні [1]. Водночас шляхи досягнення цього результату відрізняються залежно від виду та обставин злочину. Кримінальні правопорушення, вчинені із використанням безготівкових операцій, є специфічними за своєю природою, оскільки вчиняються в царині новітніх технологій, що регламентовано специфічними галузями знань, посягають на нематеріальний за фізичною природою предмет - безготівкові кошти. У зв'язку з цим із передбачених ст. 84 КПК України джерел отримання доказів вирішальну роль у цих провадженнях відіграють речові докази та висновки експертів.

Постановка завдання. Метою статті є аналіз нормативного закріплення інститутів судових експертиз, речових доказів та арешту майна на предмет можливості їх ефективного застосування у кримінальних провадженнях, вчинених із використанням безготівкових операцій.

Результати дослідження. Проблематика ефективності протидії злочинам, вчиненим із використанням безготівкових операцій, у різних її аспектах є досить обговорюваною серед наукових і практичних працівників. Найбільший вклад у вивчення цієї категорії правопорушень та окремих процесуальних інститутів здійснили Г.С. Бідняк, А.Ф. Волобуєв, В.В. Корнієнко, Т.А. Пазинич, О.В. Пчеліна, П.П. Чеберяк та інші.

У науковій і методичній літературі до основного напряму проведення експертиз у кримінальних провадженнях щодо злочинів, вчинених із використанням безготівкових операцій, відносять комп'ютеро-технічні експертизи [2, с. 58]. Значення висновку експерта як джерела доказів важко переоцінити, оскільки він зазвичай є визначальним доказом вини правопорушника. До видів комп'ютеро-технічних експертиз належать:

Експертиза комп'ютерної техніки, яка встановлюе факти закономірності функціонування та експлуатації комп'ютерної системи.
Експертиза програмних продуктів, яка визначає функціональне призначення, технічні параметри, вимоги, алгоритми, структури, стан та особливості програмного забезпечення.

Інформаційно-комп'ютерна експертиза, яка встановлює закономірності створення, обробки та збереження інформації на комп'ютерних носіях. Ïї завданням є пошук, виявлення, відтворення й технічний аналіз інформації, створеної користувачем чи програмами в комп'ютерній системі [3].

Активний розвиток технологій, зростання рівня технічного забезпечення повсякденного життя, розвиток інтерфейс-програм, які дозволяють доступ до банківських рахунків із телефонних пристроїв, зумовлює ситуацію, за якої сліди злочинів відображаються не тільки і не стільки на технічних пристроях, скільки в мережі. Поширення телекомунікаційних технологій зумовило виокремлення телекомунікаційної експертизи, яка ще $€$ недостатньо розробленою з точки зору методики та методології її проведення. Варто також зазначити, що обсяг цього експертного дослідження має динамічний характер внаслідок постійного розвитку технологій.

При заволодінні безготівковими коштами важливо встановити спосіб, у який здійснено доступ до рахунку. В банківських установах це питання перебуває у компетенції фахівців із безпеки, які на базі економічних та технічних знань встановлюють механізм дії правопорушника. Щоб встановити вказані обставини у кримінальному провадженні, необхідно призначення кількох експертиз, що істотно затягує строки досудового розслідування. За таких обставин розвиток експертних досліджень, на думку автора, повинен бути спрямований на забезпечення дослідження способу заволодіння безготівковими коштами шляхом аналізу віртуальних слідів, залишених правопорушником у мережі.

Висновок експерта є вершиною піраміди доказування, в той час як в її основу покладено інше процесуальне джерело доказів - речові докази, збереження яких згідно зі ст. 170 КПК України забезпечується шляхом накладення арешту. На жаль, регламентація інститутів речових до- 
казів та арешту майна є не досконалою, а в деяких моментах і суперечливою, що не дозволяє ефективно їх застосовувати у кримінальних провадженнях про злочини, вчинені із використанням безготівкових операцій.

Практичне застосування цих інститутів засвідчує наявність таких проблем правозастосування:

1) Чинні положення КПК України не забезпечують можливість поновлення прав потерпілих на стадії досудового розслідування. Так, з аналізу положень ст. 100 КПК України вбачається, що повернення речей, вилучених у особи, яка заволоділа майном внаслідок кримінального правопорушення, на стадії досудового розслідування не можливе. Визначення долі речових доказів, які не містять слідів кримінального правопорушення, в тому числі на які накладено арешт, передбачено ч. 6 ст. 100 КПК України, виключно щодо таких категорій:

1) предмети, великі партій товарів, зберігання яких через громіздкість або з інших причин не можливе без зайвих труднощів або витрати по забезпеченню спеціальних умов, зберігання яких співмірні з їх вартістю;

2) товари або продукція, які піддаються швидкому псуванню.

Попри це усталеною практикою серед слідчих є повернення потерпілим майна, яким протиправно заволоділи правопорушники, шляхом винесення постанов про зміну місця зберігання. Проте, якщо майно не належить до однієї з наведених вище категорій, то такі рішення суперечать положенням ст. 100 КПК України.

Викликає сумніви доцільність встановлення таких правових рамок. Зазвичай предмети, які були набуті внаслідок вчинення злочину, вже своїм існуванням та умовами вилучення доводять обставини, які відповідно до ст. 91 КПК України підлягають доказуванню у кримінальному провадженні. На підтвердження обгрунтованості такої тези автор моделює ситуацію, за якої протиправно отримані кошти були арештовані на банківському рахунку правопорушника. Проте поновити права потерпілого шляхом повернення майна процесуально не можливо з низки причин:

1) безготівкові кошти не віднесені до переліку видів речових доказів, визначених ч. 6 ст. 100 КПК України, щодо яких можливо прийняти рішення про їх долю на стадії досудового розслідування;

2) зміна місцезнаходження речових доказів чинним КПК України передбачена у п. 1 ч. 6 ст. 100 КПК України, яка суперечить положенням ст. 174 КПК України і не може бути практично реалізована. Так, повернення та передання речового доказу на відповідальне зберігання зі змісту п. 1 ч. 6 ст. 100 КПК України може бути здійснено слідчим, в той час як банківськими установами постанова слідчого до виконання при- йнята бути не може з огляду на положення п. 5.1. Інструкції про безготівкові розрахунки в Україні в національній валюті, якою передбачено, що відповідно до ст. 1071 Цивільного кодексу України кошти можуть бути списані з рахунку клієнта без його доручення на підставі рішення суду, а також у випадках, встановлених законом [4].

В аспекті запровадження положень ст. 219 КПК України щодо обмеження строків досудового розслідування поширеними стануть випадки необхідності закриття провадження у зв'язку із завершенням строків розслідування у кримінальних провадженнях, в яких накладено арешт. У таких випадках положення ст. 100 КПК України варто доповнити нормою про повернення коштів за спірними транзакціями первинному власнику, детальніше регламентувати порядок вирішення долі речових доказів за постановою прокурора. Вирішити цю проблему, на думку автора, можливо шляхом додаткового нормативного регулювання. Зокрема, ст. 100 КПК України автор пропонує викласти у такій редакції:

ч. 1 Речовий доказ, який був наданий стороні кримінального провадження або нею вилучений, повинен бути якнайшвидше повернутий володільцю, крім випадків, передбачених ст.ст. 160-166, 170-174 цього Кодексу, в яких речові докази повертаються власнику, законнолу володільцю за рішеннял слідчого судді, суду, постановленого за клопотаннял сторони крилінального провадження з урахуванням положень ч. 6 та 9 иієї статmі.

ч. 6 Речові докази, які не містять слідів кримінального правопорушення, а також речові докази у вигляді товарів або продукції, що піддаються швидкому псуванню повертаються власнику (законному володільцю) або передаються йому на відповідальне зберігання, якщо це можливо без шкоди для кримінального провадження, за рішенням слідчого, а щодо яких накладено арешт за рішенням слідчого судді, суду .

Така позиція зумовлена наявністю відносно тривалих часових рамок, визначених ст. 219 КПК України, у слідчого для вивчення обставин, що свідчать про наявність чи відсутність складу злочину. Якщо ж слідчий дійде висновку про відсутність складу чи події правопорушення, саме критерій часу дасть змогу насамперед вирішити питання про зняття арешту та долю вилученого майна, зокрема позбавивши своїм рішення його статусу речового доказу, та прийняти рішення в порядку ст. 284 КПК України. Натомість при оголошенні особі про підозру 2-місячний строк розслідування істотно скорочує часові рамки прийняття рішення, у зв'язку з чим автор вважає за можливе повноваження прокурора щодо скасування арешту залишити, обмеживши таке право категорією проваджень, у яких оголошено особі про підозру. 
2) Не врегульованою залишається проблема скасування арешту майна. Правом на вирішення питання про скасування арешту майна відповідно до вимог ч. 3 та 4 ст. 174 КПК України наділено суд на стадії судового розгляду, слідчого суддю та прокурора - на стадії досудового розслідування. Водночас порядок скасування арешту при закритті провадження залишається спірним. Причиною цього є певні неточності. Так, ч. 3 ст. 173 КПК України передбачено, що рішення про скасування арешту приймається прокурором одночасно із винесенням постанови. При цьому поняття «одночасно» є неконкретизованим, оскільки в цьому випадку підставу скасування арешту законодавець пов'язує із юридичним фактом закриття провадження. 3 одного боку винесення постанови про скасування арешту до винесення постанови про закриття позбавлено юридичного сенсу, з іншого - прийняття постанови після закриття провадження суперечить вимогами п. 5 ч. 1 ст. 3 КПК України 3 огляду на те, що стадія досудового розслідування закінчується прийняттям рішення про закриття, що виключає можливість прийняття будь-яких інших рішень у провадженні.

Крім того, прокурор приймає рішення про закриття у відносно невеликій кількості проваджень, а тому поза правовим регулювання залишаються провадження, в яких остаточне рішення приймається слідчими. Як зазначають A.P. Туманянц B.I. Медвєдєв, правозастосовна практика сформувала два варіанти дій: звернення слідчого із клопотанням до слідчого судді про скасування арешту майна та звернення власника [5, с. 198].

Якщо перший варіант прямо суперечить вимогам законодавства, бо ні слідчий, ні прокурор ст. 174 КПК України не визначені як суб'єкти, які мають право ініціювати зняття чи скасування арешту, то другий - суперечить принципу диспозитивності. В останньому випадку держава в особі правоохоронних органів утримує майно без достатньої правової підстави, при цьому повернення майна ставиться в залежність від активної позиції власника чи законного володільця майна щодо визнання дій слідчого / прокурора незаконними та скасування арешту.

Тому переважна більшість науковців схиляються до думки про доцільність внесення змін до ст. 174 КПК України. Так, А.В. Дрозд пропонує вирішити проблему шляхом відтермінування набрання чинності рішення прокурора до спливу 10-денного строку, визначеного ст. 304 КПК України для оскарження рішення про закриття провадження [6, с. 168]. Проте вказана позиція не передбачає механізму подальшої реалізації рішення про скасування арешту. 3 огляду на це автор пропонує положення ч. 1 ст. 174 КПК Укра- їни доповнити в частині надання повноважень слідчому та прокурору на звернення до слідчого судді з клопотання про скасування арешту, а ч. 3 ст. 174 КПК викласти у такій редакції: прокурор у постанові про закриття кримінального провадження, в якому особі оголошено про підозру, скасовує арешт майна, якщо воно не підлягає спеціальній конфіскації.

Очевидно, що винесення ухвали про накладення арешту, як і про скасування арешту, ще не означає застосування чи скасування заходу забезпечення. Особливо актуальне це питання у кримінальних провадженнях, вчинених із використанням безготівкових операцій, оскільки володіння безготівковими коштами опосередковане фінансовою установою, а також в умовах, коли реалізація правомочностей власника об'єкту опосередкована певними інституціями, такими як державні реєстратори (щодо нерухомого майна), сервісні центри Національної поліції (щодо транспортних засобів).

Як наслідок з часу постановлення ухвали слідчого судді до фактичного накладення арешту може проходити тривалий час. При цьому кримінальне процесуальне законодавство відповідальність за негайне виконання ухвали про арешт покладає на слідчого, прокурора навіть попри те, що у наведених прикладах ці питання знаходяться поза межами їх компетенції, а регламентовані відповідними відомчими актами.

На увагу в аспекті вирішення цієї проблеми заслуговує практика функціонування Інформаційної системи грошових обмежень (PLAIS) в Литві та Автоматизованої інформаційної системи виконання грошових зобов'язань (АИС ИДО) в Білорусі. У вказаних державах запроваджено функціонування міжвідомчих інформаційних систем, які забезпечують невідкладний обмін офіційними документами 3 питань арешту між відомствами. Організація виконання ухвали про арешт покладається на суд, який ухвалив рішення, шляхом скерування рішення до інформаційної системи, а накладення арешту відбувається в автоматичному режимі [7].

В таких умовах постановлення рішення про арешт чи зняття арешту фактично не розподілені в часі з реальним його застосуванням. Натомість до запровадження функціонування аналогічної міжвідомчої інформаційної системи на теренах України з метою забезпечення дієвості арешту як заходу забезпечення, оперативності досягнення цілей його застосування та недопущення порушення майнових прав осіб, на майно яких накладено арешт, необхідно передбачити порядок і строки реалізації ухвал про арешт посадовими особами, яких вони стосуються. Так, ст. 175 КПК України автор пропонує викласти у такій редакції: «Виконання ухвали про арешт майна та скасування арешту майна». 
1. Ухвала про арешт майна слідчим, прокурором негайно виконується або надається для виконання органу чи посадовій особі, уповноваженим на її виконання.

2. Слідчий, прокурор надає для виконання ухвалу про арешт шляхом ї доставлення особисто, направлення рекомендованим або цінним листом, електронною поштою з дотриманням вимог законодавства України з питань електронного документообігу, електронних довірчих послуг, захисту інформації.

3. Орган чи посадова особа, уповноважені на виконання постанови, зобов'язані виконати їі протягом 1 робочого дня, про що невідкладно письмово повідомити відповідного слідчого чи прокурора.

Необхідно також передбачити у ст. 175 КПК України заходи відповідальності за невиконання чи несвоєчасне виконання ухвали про арешт та порушення строків інформування органу слідства. На думку автора, вирішенням проблеми скасування арешту може бути врахування змін щодо строків досудового розслідування. Так, нині жодне провадження не може бути розслідувано 3 порушенням строків, визначених ст. 219 КПК України. Враховуючи, що арешт є засобом забезпечення кримінального провадження, то й мета його нівелюється при прийнятті одного з рішень, визначених ст. 284 КПК України.

3 метою уникнення можливих ситуацій щодо не направлення рішень про скасування арештів уповноваженим органам доцільно встановити строки дій арешту, пов'язавши його із загальними строками досудового розслідування, визначеного ст. 219 КПК України. Такий підхід дозволить захистити майнові права учасників кримінального провадження, оскільки рішення про арешт буде припинятися автоматично зі сплином строку розслідування, буде дисциплінувати слідчих і прокурорів в частині доцільності майнових обмежень. Водночас дія арешту може бути продовжена із вирішенням питань про продовження строків досудового розслідування в порядку, передбаченому параграфом 4 глави 23 КПК України. Це розши- рить можливості судового контролю цього заходу забезпечення.

Висновки. Проведене дослідження засвідчило, що технічний прогрес вимагає вдосконалення інституту доказування у кримінальному провадженні. Ефективна протидія злочинам, вчиненим із використанням безготівкових операцій, не можлива без розробок нових методик експертних досліджень, вдосконалення існуючих процесуальних процедур виявляння та арешту майна як основного засобу не лише збереження речових доказів, але й поновлення прав потерпілого.

\section{Jimepamypa}

1. Кримінальний процесуальний кодекс України від 13.04.2012 № 4651-VI/. Офіційний сайт ВР України [Електронний ресурс]. Режим доступу: http://zakon4.rada.gov.ua/laws/show/4651-17.

2. Організація розслідування фактів несанкціонованого переказу коштів з рахунків клієнтів банку, які обслуговуються за допомогою систем дистанційного обслуговування: Методичні рекомендації / В.В. Корнієнко, В.І. Стреляний. X., 2015. 71 с.

3. Експертиза комп'ютерної техніки і програмних продуктів або комп'ютерно-технічна експертиза. Протокол: юридичний інтернет-ресурс.

4. Інструкції про безготівкові розрахунки в Україні в національній валюті : постанова НБУ від 21.01.2004 № 22 / Офіційний сайт ВР України [Електронний ресурс]. Режим доступу: https://zakon.rada.gov.ua/laws/ show/z0377-04.

5. Туманянц А.P., Медвєдєв B.I. Арешт майна у кримінальному провадженні: окремі проблеми застосування. Право і суспільство. 2018. № 2 частина 3. C. 194-199. URL: http://pravoisuspilstvo.org.ua/ archive/2018/2_2018/ part_3/38.pdf (дата звернення:15.04.2020).

6. Дрозд А.В. Деякі проблемні питання арешту майна в кримінальному провадженні. Науковий вісник Міжнародного гуманітарного університету. Серія: Юриспроденція, 2018. Том. 2. № 36. С. 164-168. URL: http://vestnik-pravo.mgu.od.ua/archive/juspradenc36/ part 2/juspradenc36-2.pdf\#page=164 (дата звернення: 15.0̄ .2020 )

7. Авторгов А. Автоматизований арешт рахунків: боржники можуть спати спокійно? Платформа ЛIГА:ЗАКОН. URL: https://jurliga.ligazakon. net/experts/27/923_avtomatizovaniy-aresht-koshtvborzhniki-mozhut-spati-spokyno. 


\section{Анотація}

Чемерис I. М. Використання спеціальних знань, призначення експертиз та арешт безготівкових коштів як засіб забезпечення подальших слідчих дій. - Стаття.

У статті розглянуто процесуальні джерела доказів, що найбільше притаманні досудовому розслідуванню кримінальних проваджень про злочини, вчинені із використанням безготівкових операцій, а саме висновок експерта та речові докази. Досліджено комп'ютеро-технічні експертизи як такі, що найчастіше призначаються у провадження цієї категорії. Розкрито зміст експертизи комп'ютерної техніки, експертизи програмних продуктів, інформаційно-комп'ютерної експертизи, вивчено відмінності між ними. Звернуто увагу на потенціал розвитку відносно нового виду експертного дослідження - телекомунікаційної експертизи, методика та методологія якої розроблені ще недостатньо. Проаналізовано статус речей, зумовлений визнанням їх речовими доказами та накладенням арешту на них.

У дослідженні проводиться аналіз механізмів поводження із речовими доказами та арештованим майном, звертається увага на суперечності нормативно-правового регулювання щодо визначення долі речових доказів, на які накладено арешт. У статті акцентується увага на наявних практичних проблемах, які виникають при реалізації ухвал суду про арешт майна, неможливості забезпечити повернення майна, набутого внаслідок вчинення кримінального правопорушенням, потерпілому на стадії досудового розслідування.

В умовах обмежених строків досудового розслідування запропонований механізм реалізації права потерпілого на відшкодування шкоди, завданої кримінальним правопорушенням. 3 урахуванням практики інших держав висловлено необхідність запровадження системи автоматичної реалізації ухвал суду про накладення арешту на майно. На підставі проведеного вивчення запропоновано розширити перелік суб'єктів, уповноважених на звернення із клопотанням про скасування арешту майна.

Істотно удосконалено порядок припинення арешту при закритті кримінального провадження та скасування арешту майна у кримінальних провадженнях щодо злочинів, вчинених із використанням безготівкових операцій. Зокрема, наводяться пропозиції щодо закріплення порядку визначення долі речей, які не містять слідів кримінального правопорушення, як в ході досудового розслідування, так і при прийнятті остаточного рішення у кримінальному провадженні.

Ключові слова: комп'ютеро-технічна експертиза, телекомунікаційна експертиза, речові докази, арешт майна, безготівкові кошти, відшкодування шкоди.

\section{Summary}

Chemerys I. M. Use of special knowledge and appointment of expert examinations and freezing of noncash resources as a means for ensuring the further investigative actions. - Article.

The article examines the procedural sources of evidence that are most relevant to the pre-trial investigation of criminal proceedings involving crimes involving the use of non-cash transactions, namely: expert's opinion and material evidence. Computer-aided examinations have been investigated as those most commonly assigned to this category. The content of computer hardware examination, software examination, information and computer examination is revealed, the differences between them are studied. Attention is drawn to the potential for the development of a relatively new type of expert research - telecommunication expertise, methods and methodology of which have not been sufficiently developed.

The status of things due to the recognition of their material evidence and the seizure of them is analyzed. The study analyzes the mechanisms of dealing with material evidence and seized property, and draws attention to the contradictions of the legal regulations regarding the determination of the fate of material evidence that has been seized. The article focuses on the practical problems encountered in the implementation of court decisions on the seizure of property, the inability to secure the return of property acquired as a result of a criminal offense suffered during the pre-trial investigation.

In the limited time of pre-trial investigation, a mechanism for exercising the victim's right to compensation for damage caused by a criminal offense is proposed. Taking into account the practice of other states, it is necessary to introduce a system of automatic implementation of court decisions on seizure of property. Based on the study, it is proposed to expand the list of subjects authorized to petition for the cancellation of property seizure.

The procedure for termination of arrest at the closure of criminal proceedings and cancellation of arrest of property in criminal proceedings for crimes committed using non-cash transactions has been significantly improved. In particular, proposals are made to consolidate the procedure for determining the fate of things that do not contain the traces of a criminal offense, both during the pre-trial investigation and in the final decision in criminal proceedings.

Key words: computer expertise, telecommunication expertise, material evidence, seizure of property, noncash, damages. 